\title{
AGAIN ON THE CONSTITUTIVE OR TRANSFERRING EFFECT OF PROPERTY- RELATED RIGHTS OF THE REGISTRATION WITH THE LAND BOOK Gina ORGA-DUMITRIU
}

\author{
"Lucian Blaga" University, Sibiu, Romania \\ ginadumitriu@yahoo.com
}

\begin{abstract}
Initially regulated by the provisions of art. 17 in the Decree - law no. 115/1938, subsequently dethroned by the provisions of Law no. 7/1996 and reaffirmed by the provisions of art. 885-886 in the new Civil Code, a lot was written about the principle of the constitutive or transferring effect of property-related rights of the registration with the land book. The principle of the opposability towards third parties of the registrations in the transcription and inscription registers vs. the principle of the constitutive or transferring effect of the registrations with the land book are the disjunctive categories representing the basis of the traditional dichotomy between the land recordation personal system and the real land recordation system. This study proposes a radiography of the theoretical and particularly the practical significances in terms of the content, the field of application and the exceptions from the principle of the constitutive effect in the regulation of the new Civil Code, not saving a comparative analysis with the opposability effect of the entries pursuant to Law no. 7/1996.
\end{abstract}

Keywords: the principle of the rights transferring effect or the constitutive effect, land books, the opposability toward third parties

Preamble. Having the value of a reference principle in the hierarchy of the rules established by the Decree-law no. $115 / 1938$, the principle of the rights constitutive effect of the registration with the land book did not seduce the law-maker having passed Law no. 7/1996 for which it remained a "sleeping beauty" that only the New Civil Code "kissed" and really woke up. As an analysis of the principle exclusively in reference to the provisions 885-887 in the New Civil Code would definitely be a fragmentary one, a short descriptive of the legislative adventure that the principle of the constitutive effect went through in three historical-legislative stages, representative for the regulation of the land registry in our country becomes necessary (I). It is only then that we will proceed to more detailed developments on the legal regime of the principle in the current regulation, more precisely on the content and exceptions encountered by the application thereof (II).

I. Summarized History of an Essential Principle

§1. Introduction of the principle of the constitutive effect in the Romanian law by the Decree-law no. 115/1938

1. Content of the principle. From the initial establishment thereof by the Decreelaw no. 115/1938, to the dethronement occurred by Law no. 7/1996 and the reentry by the New Civil Code, the principle of the constitutive effect of the registration with the land book is the beneficiary of a historical page marked by enthusiastic affiliations, questions and legal controversies. 
Applicable in Transylvania over the period of the Hapsburg domination (and after the political compromise of 1857 , the AustroHungarian one) within the meaning of the (land book) Regulations of 1855 and 1870 under the name of the ,fundamental principle of registration" or the ,principle of inscription" [1], the principle of the property-related rights constitutive effect of the registration was introduced in our legislation by the Decree-law no. 115/1938 having the value of a reference principle for the land book principles in general and for the principle governing the effects of inscriptions in particular.

Interpreting the provisions of art. 17 paragraph (1) of the decree-law, according to which "the property-related rights on the real properties will be acquired only if, between the giver and the taker, there is an agreement on the establishment or change of venue, within the meaning of an indicated cause, and the establishment or the change of venue was registered in the land book", it results that the acquirement of the transmission of property-related rights takes place subject to the cumulative meeting of two conditions: the agreement of the parties and the registration of the right with the land book. The agreement of the parties results only in an obligation-based legal relation, i.e. claim in favour of the acquirer, namely the right to acquire a real property by registration and of a correlative obligation of the other party, namely of delivering the deed necessary for the tabulation. The obligation-based right is extinguished by registration and the right in rem arises. From this perspective, it is also retained that the land book system provides a balance between the static security and the dynamic security of the civil circuit [2].

2. Exceptions from the principles of the constitutive effect: unregistered rights in rem. The exceptions from the rule of the rights constitutive or transferring effect of the registration with the land book are regulated by art. 26 in the decree-law, speaking of the so-called unregistered rights in rem, which are acquired without registration with the land book, namely the rights in rem acquired by succession, accession, force sale and expropriation. In the former Regulations of 1855 and 1870, the absolute principle of the registration whereby the rule itself was exteriorized was differentiated from the relative principle of the registration practically covering the exceptions from the rule of principle [3]. However, the holder of these rights will be able to dispose of them only after the registration thereof with the land book.

§2. Triumph of the consensuality principle and the consequences thereof: the effect of opposability of the registration towards third parties removes the right constitutive effect of the registration

3. Possible justifications for the establishment of the opposability effect of the registrations. The elaborators of Law no. 7/1996 considered that the solution of the opposability of the registrations towards third parties (applicable in the personal land registry systems via the registers of transcriptions and inscriptions) would be closed to the consensuality principle established by the provisions of our Civil Code (art. 971, 1295 in the Civil Code), not being excluded for this option to have been preferred in a spirit of continuity as well, in the sense that the principle of opposability was to be found not only in the draft of the Civil Code of 1971[4], but it was subsequently even set forth by art. 75 of Law no. 59/1974 on the land resources.

4. Opposability solution: content and exceptions. The effect of opposability of the registrations towards third parties results from the interpretation of the provisions of art. 22 paragraph (1) in the initial form of Law no. 7/1996, respectively it was expressly established by art. 25 paragraph (1) - in the form acquired after republication (following the amendment by Law no. 247/2005) - according to which "The registrations with the land book will produce their effects of opposability 
towards third parties as of the application registration date; the order of registration of the applications will determine the rank of the registrations". Whereas, between the parties, the legal document produced its effects as of the valid conclusion thereof, irrespective of whether the right was registered in the land book or not, towards third parties, the absence of the registration makes the right in rem non-opposable.

5. From the principle of opposability of the registration towards third parties, a series of exceptions have been established, restrictively enumerated by art. 26 paragraph (1) of the law, the case in which property-related right in rem was acquired by succession, accession, forced sale and prescription being concerned; at the same time, pursuant to paragraph (2) the rights in rem acquired by the State and by any person in virtue of the law, by expropriation or by judgments are opposable towards third parties in the same conditions. As it can be noted, manners of property acquirement exterior to the will of the parties are concerned. The established exceptions are mainly motivated by the circumstance legal documents or deeds non-susceptible of immediate publicity are concerned (such as the case of the succession transmission or prescription) and, in other cases, actions subject to specific formalities are concerned (such as the force sale by public tender) [5]. Similar to the unregistered rights in rem regulated by the Decree-law no. 115/1938, and in the case of the exceptions from the principle of opposability, the holder of the rights acquired in the enumerated manners can, however, dispose thereof only after having been previously registered with the land book [art. 26 paragraph (3)].

6. Critique of the approach proposed by Law no. 7/1996 as regards the effects of the registration. The legislative solution of the opposability of the registration towards third parties for which the authors of Law no. 7/1996 opted was considered vulnerable, especially in consideration of the severalty of the transferring effects of the conventions in two successive moments - the moment of conclusion of the agreement on the arising of the rights between the parties (inter partes) and the moment of the registrations in the relations with the third parties [6]. Practically, within the same legal operation, two different manners in which the transfer of propertyrelated rights in rem is operated are recognized: solo consensu in the relations between the parties and as of the registration date, in the relations with the third parties, creating the conditions for the occurrence of equivocal and pernicious legal situations [7] and definitely affecting the security of the civil circuit. This legal paradox: the occurrence of an (absolute) right in rem non-opposable to third parties [8] denunciated by the doctrine seems not to have left the law-maker totally indifferent since, on a more rigorous analysis of the provisions of Law no. 7/1996, in the form acquired after the amendments operated by Law no. 247/2005, we may ascertain that the law-maker seems to make, however, some concessions to the rights constitutive effect.

7. Compromises and inconsistencies. Thus, from reading the provisions of art. 20 paragraph (2) according to which "The rights in rem are extinguished only by the registration of the deregistration thereof from the land book, with the consent of the holder of the right", it results that the rights constitutive effect operates only in reference to the extinguishment of the rights in the land book. The conduct of the law-maker, which seems "to have been tempted to return to the rights constitutive system adopted by the Decree-law no. 115/1938, but, probably got scared or believed it was not the right moment, as it stopped half-way through"[9] is the sign of a certain insistency which is also preserved by a certain tension felt between the content of art. 25 paragraph (1) and 47 paragraph (6) of the law (take over from the former art. 111 of the Decree-law no. 115/1938). Whereas the first established the principle 
of opposability, the other one stipulates that

"The tabulation or the provisory registration may be requested by any person who, according to the original deed, the judgment or the resolution of the administrative authority, is going to change the venue, establish, amend, acquire or extinguish a tabular right". Consequently, it results from reading the text that the document contemplating the transfer, establishment, amendment or extinguishment of a property-related right in rem is not transferring, establishing, amending or extinguishing rights between the parties, this effect being produced as of the registration date.

The fact that, by the provisions of the New Civil Code, the law-maker considered its option seems to be the extended effect of the awareness of the benefits of the constitutive effect and an adjusted reaction to the dominant voice of the doctrine.

§3. Revalorization of the traditional approach: re-entry of the constitutive effect in the New Civil Code

8. General consideration of the re-entry of the principle of the constitutive effect in the New Civil Code. By the regulation of the rights constitutive or transferring effect by art. 885 and 886 in the New Civil Code, we actually assist to the recovery by the law-maker of the New Civil Code of the tradition page wasted by Law no. 7/1996 and we are almost no longer surprised that the principle of the constitutive effect continues to create controversies at the present moment too [10]. Subject to contrary legal provisions, the legal document or deed is not sufficient in itself to produce its property-related rights constitutive, transferring, amending or extinctive effects, the fulfillment of the land registry formalities being necessary, i.e. the registration or the deregistration, as applicable.

9. Due application of the legal provisions on the property-related rights constitutive effect of the registration with the land book. We remind the fact that, according to art. 56 paragraph (1) LPA, the provisions of art. 885 paragraph (1) and art. 886 in the New Civil Code are applied only after the completion of the cadastre work for each administrative-territorial unit and the opening, upon request or ex officio, of the land for the respective real properties, in compliance with the provisions of Law no. 7/1996, republished, with the subsequent amendments and supplements. Up to that date, it is further indicated in paragraph (2) of the same article, "the registration of the ownership and of other rights in rem with the land register, based on the documents whereby they were validly transferred, established or amended, is made only for the purpose of opposability towards third parties".

II. Rights constitutive effects of the registration with the land book in the New Civil Code

\section{\$1. Content}

10. Property-related rights constitutive, transferring or amending effect of the registration with the land book. The general rule comprised in art. 885 paragraph (1) in the New Civil Code is subject to particular applications, by special provisions applicable to some determined rights in rem; it is the case of the acquirement of ownership art. 557 paragraph (4) in the New Civil Code, of the establishment of the beneficial ownership, pursuant to art. 704 in the New Civil Code, of the right of use and homestead right art. 754 in the New Civil Code, of the superficies right, art. 693 paragraph (2) in the New Civil Code, the establishment of the easement right art. 756 in the New Civil Code, the mortgage right, the provisions of art. 2377 in the New Civil Code. In fact, even from the general norm comprised in art. 885 paragraph (1) in the New Civil Code, it could be ascertained that the rule of the constitutive effect operates regarding all the tabular rights (main rights in rem or accessory rights in rem) subject to contrary legal provisions. However, the law-maker will understand to regulate exceptions too, 
such as the case of the unregistered rights in rem (art. 887 in the New Civil Code) or the retention right (art. 2498 in the New Civil Code).

In the case of the rights constitutive or transferring effect of the registration with the land book, the expression of an independent consent for the registration of the acquired or transferred right is not necessary, the presentation of the application supporting document or deed being sufficient.

The rule established by art. 885 paragraph (1) in the New Civil Code is also applicable as regards the amendment of the rights in rem over real properties, unless otherwise disposed by law (art. 886 in the New Civil Code).

11. Rights extinctive effect of the deregistration of the registration with the land book. In the application of the symmetry rule, the extinguishment of the property-related rights in rem takes place only by the deregistration thereof from the land register, with the holder's consent, manifested under the form of an authentic notarial deed. Unlike the establishment, the transfer or amendment of a property-related right in rem, in case of the extinguishment thereof, the holder's consent in the sense of the deregistration of the extinguished right must be expressly expressed, distinct from the legal document wherefrom the loss or extinguishment of that right results.

12. Exceptionally, the deregistration of the registration of a property-related right in rem from the land book may take place without the express consent of the holder thereof, in the following situations:

- if the right is extinguished upon the reaching of the term indicated in the registration; as an example, the superficies right is extinguished, pursuant to art. 698 letter a), by the deregistration thereof from the land book upon the expiry of the term;

- by the death of the natural person holder of the property-related right in rem or by the termination of the legal existence of the legal entity holder; as an illustration, the beneficial ownership is mainly extinguished pursuant to art. 746 paragraph (1) in the New Civil Code, by the death of the beneficial owner or, as applicable, the termination of the legal status.

The right extinctive effect will produce in the aforementioned situations also as of the deregistration date and not as of the term reaching date, the date of the death or termination of the legal existence of the holder of the right. Certainly, the deed supporting the extinguishment of the right will also be enclosed to the application of deregistration of the tabular right registration.

We find particular applications of the general rule contained by art. 885 paragraph (2) in the New Civil Code in terms of the extinguishment of the ownership, within the meaning of the authentic waiver to this right [art. 562 paragraph (2) in the New Civil Code], of the beneficial ownership right (art. 746 paragraph (3) in the New Civil Code, of the right of use and homestead right, the incident provisions of art. 754 making reference to those on the field of the beneficial ownership, of the superficies right (art. 698 in the New Civil Code), of the easement right [art. 770 paragraph (1)in the New Civil Code] or the mortgage right [art. 2428 paragraph (1) in the New Civil Code].

13. The deregistration of a property-related right in rem does not affect the encumbrances that it is charged with, except for contrary stipulations. The rule is established by art. 885 paragraph (3) in the New Civil Code and reasserted by art. 889 on the waiving to ownership when, in paragraph (3), is is indicated that "in the case of the assets charged with propertyrelated encumbrances, the administrativeterritorial unit having taken over the asset is bound within the limit of the value of the asset".

Returning to the rule established by art. 885 paragraph (3) in the New Civil Code, we 
find special applications thereof in art. 715 in the New Civil Code paragraph (2), according to which "the leases of real properties concluded by the beneficial owners, registered with the land book, are opposable to the owner or the heirs thereof, after the extinguishment of the beneficial ownership by the death thereof or, as applicable, the termination of the legal existence of the beneficial owner, up to the reaching of the term thereof, but not for more than 3 years of the termination of the beneficial ownership". At the same time, the provisions of art. 2345 paragraph (1) in the New Civil Code indicate that "the mortgage right is maintained over the encumbered assets irrespective of the hand they are transferred to". In case the mortgage real property is sold in an auction, the ownership of the successful bidder of the real property will be tabulated "free of any mortgages or other encumbrances regarding the guarantee of the claims, the creditors being able to exercise these rights only from the obtained price (...)" [art. 856 paragraph (3) NCPC].

In case the person who has to express their consent required for the deregistration of the right groundlessly refuses to proceed accordingly, the Law Court will be able to pass a judgment making up for the consent thereof art. 885 paragraph (4) in the New Civil Code.

\section{§2. Exceptions from the principle of the right constitutive effects of the registration}

14. Comparative view. The same unregistered rights in rem are concerned, the case being taken over from the former art. 26 of the Decree-law no. 115/1938. In reference to those enumerated by art. 26 paragraph (1)-(2) of Law no. 7/1996, it can be ascertained that the prescription and the judgment were no longer preserved; the judgment because of the fact that it produces relative effects, i.e. between the parties in the trial and not towards third parties (res inter alios iudicata aliis neque nocere neque prodesse potest), and the prescription because the ascertainment of this manner of acquirement could only be recognized by a judgment too, with the same relative effects between the parties [11].

The reasoning for the regulation of the exceptions from the principle of the constitutive effect is that, in these situations, as the doctrine also remarked, since the establishment of the propertyrelated rights in rem becomes public by the legal documents or deeds that it generates themselves, the erga omnes compulsoriness of these rights is provided also without the registration with the land book [12]. However, in the case of the forced sale of a real property, the right in rem thus acquired will not be opposable to good faith third parties having acquired rights over that real property before the registration of the pursuit of the real property in the land book [art. 887 paragraph (2)].

15. Limited content of the propertyrelated rights in rem which are acquired without registration with the land book. The provisions of art. 887 paragraph (4) in the New Civil Code institute a correction on the exceptions from the principle of the constitutive effect, in the sense that the holder of the rights acquired in the manners referred to in paragraph (1) "will, be however, able to dispose thereof via the land book, only after the registration has been made" In other terms, the rights acquired without registration with the land book are deprived of the attribute of disposal, the holder thereof being able to dispose of them only after the registration has been made. In fact, the property-related rights in rem acquired as succession, forced sale or expropriation for a public utility cause are registered with the land book by the care of those dealing with the deeds afferent to these operations.

Finally, if the holder disposes of the property-related right in rem thereof, acquired within the terms of art. 887 paragraph (1) in the New Civil Code, the third acquirer will also have to ask, upon 
the application for the registration of the right thereof, the right of the author from whom they have acquired it, providing thus the application of art. 894 in the New Civil Code.

\section{References \& Bibliography}

[1] See T. Dârjan, Cartea funciară - cartea de identitate a imobilului, Hamangiu, Bucharest, 2013, p. 78.

[2] See P. Năsăudean, Publicitatea imobiliară. Cartea funciară. Analiza comparativă a Legii nr. 7/1996 şi a Decretului-lege nr. 115/1938, Hamangiu, Bucharest, 2011, p. 18.

[3] See C. Negrea, Legiuirile civile locale rămase în vigoare după extinderea legislaţiei civile a Vechiului Regat, Cartea I. Introducere.Partea I:Cărţile funciare, Librăria Cartea Românească din Cluj, Sibiu, 1944, p. 101-106.

[4] In exchange, the Civil Code of Carol II, loyal to the conception promoted by the Decreelaw no. 115/1938, had taken over the rights constitutive or transferring effects of the registrations.

[5] See C. Cucu, Legislaţia cadastrului şi a publicităţii imobiliare. Comentarii şi explicaţii, $2^{\text {nd }}$ edition, C.H. Beck, Bucharest, 2007, p. 124

[6] See M. Nicolae, Tratat de publicitate imobiliară, vol. I. Introducere în publicitatea imobiliară, Universul Juridic, Bucharest, 2006, p. 318.

[7] See Aurelia Rusu, Acţiunile de carte funciară, Hamangiu, Bucharest, 2008, p. 30.

[8] See I. Albu, Noile cărţi funciare, Lumina Lex, Bucharest, 1997, p. 15-16.

[9] See M. Nicolae, Tratat de publicitate imobiliară. Noile cărţi funciare, vol. II, Universul Juridic, Bucharest, 2006, p. 228.

[10] See T. Bodoaşcă, Opinii privind caracterul constitutiv sau translativ de drepturi reale imobiliare al înscrierilor de carte funciară, in Dreptul no. 8/2012, p. 133.

[11] See M. Mîneran. Comentariile Codului civil. Publicitatea drepturilor, a actelor şi a faptelor juridice. Cartea funciară, Hamangiu, 2012, Bucharest, p.111-112.

[12] See A. Trăilescu, in Fl. A. Baias, E. Chelaru, R. Constantinovici, I. Macovei (coordinators), Noul Cod civil. Comentariu pe articole. Art. 1-2664, CH Beck, Bucharest, 2012, p. 916. 